\title{
A COMPARISON OF SOME ANTHROPOMETRIC AND MOTOR FEATURES OF VISUALLY IMPAIRED STUDENTS WHO PLAY SPORTS AND THOSE WHO DO NOT PLAY SPORTS IN SCHOOLS FOR THE VISUALLY IMPAIRED IN TURKEY
}

\author{
Ahmet Kurtoğlu' ${ }^{1 i}$, \\ Nurettin Konar ${ }^{2}$ \\ Iİnönü University, Health Sciences Institute, \\ Department of Physical Education and Sport, \\ Malatya, Turkey \\ ${ }^{2}$ Turgut Özal University, \\ Malatya, Turkey
}

\section{Abstract:}

Purpose: The aim of this study is to compare certain anthropometric and motor features of visually impaired students who play sports and those who do not play sports in schools for the visually impaired in Turkey. It is thought that the sport has an important place in the rehabilitation of disabled people and also has an effect on their physical characteristics. Material and Methods: In this context, 98 visually impaired students who played sports regularly (72 male, 26 female) and 189 visually impaired students who did not play sports regularly (110 male, 79 female) participated in our study. In the study, participants' gender, age, height, body weight, body mass index, girth, and motor features such as flamingo balance test, flexibility, standing long jump, sit-up, bent arm hang, $10 \times 5 \mathrm{~m}$ shuttlerun, grip strength, vertical jump, abdominal strength, back strength, hip flexion strength, hip extension strength, leg flexion strength, leg extension strength, arm strength and arm extension strength were measured. During the strength measurements, Lovett's Manual Muscle Strength Test was utilised. Results: In the study, significant differences were found between visually impaired students who played sports and those who did not play sports in terms of age, height, grip strength, vertical jump, balance test, flexibility, long jump, sit-up, bent arm hang, $10 \times 5 \mathrm{~m}$ shuttle run, abdominal strength, back strength, hip flexion strength, hip extension strength, leg flexion strength, leg extension strength, arm flexion strength and arm extension strength $(p<0.05)$. However, no significant differences were found in terms of body weight, body mass index or girth $(\mathrm{p}>0.05)$. Conclusion: Examination of the test results of the study reveals that visually impaired students who played sports had higher performance levels than those of students who did not play sports. It is recommended that visually impaired

${ }^{i}$ Correspondence: email aakurtoglu@hotmail.com 
students, as well as being given physical education lessons, should take part in more mobility games and sporting activities, or that more mobility games and sporting activities should be included in course curricula.

Keywords: visually impaired, anthropometric feature, motor feature, disabled sports

\section{Introduction}

Disability is the limitation of roles expected from a person with respect to age, gender and cultural factors, or the inability to perform these roles, due to a handicap or impediment. According to the Law on People with Disabilities, enacted in July 2005, the disabled are "People who, due to any illness or accident suffered at birth or thereafter, have lost physical, mental, emotional or social faculties in varying degrees, who cannot conform to normal living requirements, who have difficulty in meeting daily needs, and who receive protection, rehabilitation, counselling and support" (1).

Sport, by freeing individuals from their isolated worlds, allows them to enter into dialogue with people, to be influenced by different environments, people, beliefs and ideas and to influence those in turn. In this way, it may be said that sport allows people to form and cement new friendships and to support social cohesion. Therefore, encouraging disabled individuals to play sports will accelerate their integration into society and make it possible for them to be included in daily life (2).

Due to the variety of disability groups and degrees of disability, the research area of disabled sports is a large one. Yet disabled sports differ from sports played by ablebodied individuals with regard to aims and goals. Disabled sports encompass all types of sporting activity for the disabled and potentially disabled, from rehabilitation sports to activities done as a hobby and performance sports. Disabled sports are aimed entirely at integration into society and at rehabilitation. Disabled sports are intended to increase the life quality of the disabled. The main aim of disabled sports is the integration of the disabled into society by encouraging their development through activities, games and sports. Rehabilitation sports are part of disabled sports and, together with other treatment methods, assist in reaching medical, career and psycho-social targets $(3,4)$.

Visual impairment is defined as "loss of sight which negatively affects an individual's educational success and which cannot be rectified". Mobility, games and physical training and sports programmes for visually impaired children should be organised in the direction of kinaesthetic and auditory stimulation. The visually impaired have the possibility to play different branches of sport according to their degree of disability. Goalball, torball, football, judo, chess and athletics are the most common branches of sport for visually impaired students and adults. These sports assist the visually impaired in terms of gaining confidence, balance, muscle control, freedom of movement and coordination and in making use of their free time. Sport provides an opportunity for eliminating fear of injury due to sight loss and for people to live more independent lives $(5,6)$. Motoric, 
physical and developmental losses show significant differences in individuals who have suffered sight loss at birth or afterwards $(7,8,9)$. In terms of sports classification, the visually impaired are classified as B1, B2, and B3, and compete with each other accordingly. Group B1 (totally blind) may perceive light but cannot distinguish the shape of a hand from any distance. Group B2 may perceive the shape of a hand, but visual acuity does not exceed 20/600 (3\%). The visual angles of group B3 are between 5-20 degrees. They have between 20/600 (3\%) and 60/600 (10\%) eyesight (9).

In our study, the aim is to determine whether there are significant differences between the anthropometric and motor features of visually impaired students aged 1215 who play sports and those who do not play sports in schools for the visually impaired in Turkey.

The demographic data of the students participating in the study were taken, some measurements in the Eurofit Test Battery and the Brockport Test of Physical Fitness were taken, and the students' upper and lower extremity muscle strength was measured with Lovett's Manual Muscle Strength Testing Technique (10, 11, 12).

\section{Materials and Methods}

The study universe is made up of 601 visually impaired students aged 12-15 studying at schools for the visually impaired in the cities of Adana, Ankara, Diyarbakır, Erzurum, Gaziantep, İstanbul, İzmir, Konya, Kahramanmaraş, Konya and Kayseri in Turkey. A total of 287 visually impaired students at these schools, 98 of whom played sports (72 male, 26 female) and 189 of whom did not play sports (110 male, 79 female), took part in our study (13).

After Power Analysis ( $\alpha=0.051-\beta$ (power)=0.80) was applied to determine the sample group, it was established that there should be a total of 284 participants, of which 142 played sports and 142 did not play sports. The necessary permission for our study was obtained from the Directorate General for Special Education and Guidance Services. Secondary school students who regularly took part in any training programme and students who did not take part in any training programme participated in our study. 98 students who played sports, with ages of $13.73 \pm 1.44$, heights of $158.62 \pm 12.13$, body weights of $50.09 \pm 16.58$ and body mass indices (BMI) of 19.57 \pm 4.42 ; and 189 students who did not play sports, with ages of $13.14 \pm 1.51$, heights of $151.20 \pm 10.70$, body weights of $46.77 \pm 16.63$ and body mass indices (BMI) of 20.08 \pm 5.20 , participated.

Details and possible risks of the research were explained to all participants in the study. Parents signed forms to confirm that the participants took part in the research voluntarily. The study was approved by the Clinical Research Ethics Committee of Inönü University. 


\section{Findings}

Examination of Table 1 shows that although there were differences between some personal characteristics of male visually impaired students who played sports and those who did not, such as age, body weight and body mass index, in favour of students who played sport, no statistically significant difference was found ( $p>0.05)$. When examining body mass index, it may be said that both groups were of normal weight (18.5 - 24.9) $(14,15,16)$. Since students who played sports were tall, a significant difference was found between average height of male visually impaired students who played sports and male visually impaired students who did not play sports $(\mathrm{p}<0.05)$.

Table 1: Comparison of Some Personal Characteristics of Male Visually Impaired Students Playing Sports and of Male Visually Impaired Students Not Playing Sports

\begin{tabular}{|l|c|c|c|c|}
\hline Parameters & $\begin{array}{c}\text { Playing Sports } \\
(\mathbf{n = 7 2}) \mathbf{X} \pm \mathbf{s s}\end{array}$ & $\begin{array}{c}\text { Not Playing Sports } \\
(\mathbf{n = 1 1 0 )} \mathbf{X} \pm \mathbf{s s}\end{array}$ & $\mathbf{t}$ & $\mathbf{p}$ \\
\hline Age (years) & $13.76 \pm 1.49$ & $13.40 \pm 1.55$ & 1.526 & .129 \\
\hline Height $(\mathrm{cm})$ & $159.33 \pm 13.22$ & $152.76 \pm 11.25$ & 3.590 & $.000^{*}$ \\
\hline Body Weight $(\mathrm{kg})$ & $50.85 \pm 18.23$ & $48.19 \pm 17.93$ & .974 & .331 \\
\hline BMI $\left(\mathrm{kg} / \mathrm{m}^{2}\right)$ & $19.56 \pm 4.41$ & $20.24 \pm 5.45$ & -.877 & .382 \\
\hline
\end{tabular}

*Significance level was set at $\mathrm{p}<0.05$.

Examining Table 2, since female visually impaired students who played sports were older and taller than students who did not play sports, a statistically significant difference was found between them $(\mathrm{p}<0.05)$. As for personal characteristics like body weight and body mass index, however, no statistically significant difference was found, as with the male students $(\mathrm{p}>0.05)$.

Table 2: Comparison of Some Personal Characteristics of Female Visually Impaired Students Playing Sports and of Female Visually Impaired Students Not Playing Sports

\begin{tabular}{|l|c|c|c|c|}
\hline Parameters & $\begin{array}{c}\text { Playing Sports } \\
(\mathbf{n = 2 6 )} \mathbf{X} \pm \mathbf{s s}\end{array}$ & $\begin{array}{c}\text { Not Playing Sports } \\
(\mathbf{n = 7 9 )} \mathbf{X} \pm \mathbf{s s}\end{array}$ & $\mathbf{t}$ \\
\hline Age (years) & $13.57 \pm 1.27$ & $12.82 \pm 1.43$ & 2.394 & $\mathbf{p}$ \\
\hline Height $(\mathrm{cm})$ & $156.65 \pm 8.27$ & $149.02 \pm 9.54$ & 3.646 & $.000^{*}$ \\
\hline Body Weight $(\mathrm{kg})$ & $47.98 \pm 10.79$ & $44.79 \pm 14.53$ & 1.029 & .306 \\
\hline BMI $\left(\mathrm{kg} / \mathrm{m}^{2}\right)$ & $19.58 \pm 4.52$ & $19.86 \pm 4.85$ & -.251 & .803 \\
\hline
\end{tabular}

${ }^{*}$ Significance level was set at $\mathrm{p}<0.05$.

Examination of Table 3, in which average girth measurements of shoulder, chest, upper arm, abdomen, hip, upper leg and lower leg in male visually impaired students who played sports and those who did not play sports are compared, shows that no significant difference could be found ( $p>0.05)$. 
Table 3: Comparison of Girth Measurements of Male Visually Impaired

Students Playing Sports and of Male Visually Impaired Students Not Playing Sports

\begin{tabular}{|l|c|c|c|c|}
\hline Parameters & $\begin{array}{c}\text { Playing Sports } \\
(\mathbf{n = 7 2 )} \mathbf{X} \pm \mathbf{s s}\end{array}$ & $\begin{array}{c}\text { Not Playing Sports } \\
(\mathbf{n = 1 1 0 )} \mathbf{X} \pm \mathbf{s s}\end{array}$ & $\mathbf{t}$ & $\mathbf{p}$ \\
\hline Shoulder Girth (cm) & $94.38 \pm 15.98$ & $92.04 \pm 14.20$ & 1.035 & .302 \\
\hline Chest Girth (cm) & $76.30 \pm 9.67$ & $76.82 \pm 10.70$ & -.334 & .739 \\
\hline Upper Arm Girth (cm) & $22.12 \pm 3.57$ & $22.26 \pm 4.13$ & -.233 & .816 \\
\hline Abdominal Girth (cm) & $69.37 \pm 11.51$ & $71.47 \pm 13.47$ & -.986 & .325 \\
\hline Hip Girth (cm) & $82.36 \pm 12.65$ & $80.25 \pm 14.66$ & -1.086 & .279 \\
\hline Upper Leg Girth (cm) & $39.05 \pm 6.21$ & $38.64 \pm 8.03$ & .367 & .714 \\
\hline Lower Leg Girth (cm) & $29.90 \pm 5.15$ & $29.47 \pm 5.05$ & .557 & .578 \\
\hline
\end{tabular}

${ }^{*}$ Significance level was set at $\mathrm{p}<0.05$.

When the Table 4 is examined, as in the male students, no statistically significant difference could be found between average girth measurements of shoulder, chest, upper arm, abdomen, hip, upper leg and lower leg in female visually impaired students who played sports and those who did not play sports $(\mathrm{p}>0.05)$.

Table 4: Comparison of Girth Measurements of Female Visually Impaired Students Playing Sports and of Female Visually Impaired Students Not Playing Sports

\begin{tabular}{|l|c|c|c|c|}
\hline Parameters & $\begin{array}{c}\text { Playing Sports } \\
(\mathbf{n = 2 6 )} \mathbf{X} \mathbf{s s}\end{array}$ & $\begin{array}{c}\text { Not Playing Sports } \\
(\mathbf{n = 7 9 )} \mathbf{X} \pm \mathbf{s} \mathbf{s}\end{array}$ & $\mathbf{t}$ & $\mathbf{p}$ \\
\hline Shoulder Girth (cm) & $91.96 \pm 8.34$ & $90.60 \pm 16.27$ & .406 & .686 \\
\hline Chest Girth (cm) & $77.69 \pm 9.69$ & $76.49 \pm 10.32$ & .521 & .603 \\
\hline Upper Arm Girth (cm) & $22.07 \pm 2.78$ & $21.87 \pm 4.08$ & .236 & .814 \\
\hline Abdominal Girth (cm) & $68.92 \pm 9.43$ & $69.78 \pm 12.25$ & -.328 & .744 \\
\hline Hip Girth (cm) & $83.92 \pm 10.53$ & $82.07 \pm 12.38$ & .683 & .496 \\
\hline Upper Leg Girth (cm) & $38.88 \pm 5.22$ & $38.36 \pm 6.46$ & .370 & .712 \\
\hline Lower Leg Girth (cm) & $30.42 \pm 6.79$ & $29.05 \pm 4.94$ & 1.114 & .268 \\
\hline
\end{tabular}

*Significance level was set at $\mathrm{p}<0.05$.

Examination of Table 5 reveals that significant differences were found between averages of grip strength, vertical jump, flamingo balance test, sit-reach test, standing long jump, sit-up test, bent arm hang and10x5 shuttle run in male visually impaired students who played sports and those in male visually impaired students who did not play sports $(\mathrm{p}<0.05)$.

Table 5: Comparison of Motor Features of Male Visually Impaired Students Playing Sports and of Male Visually Impaired Students Not Playing Sports

\begin{tabular}{|l|c|c|c|c|}
\hline Parameters & $\begin{array}{c}\text { Playing Sports } \\
(\mathbf{n = 7 2 )} \mathbf{X} \pm \mathbf{s s}\end{array}$ & $\begin{array}{c}\text { Not Playing Sports } \\
(\mathbf{n = 1 1 0 )} \mathbf{X} \pm \mathbf{s s}\end{array}$ & $\mathbf{t}$ & $\mathbf{p}$ \\
\hline Grip Strength $(\mathrm{kg})$ & $36.80 \pm 20.40$ & $24.58 \pm 19.45$ & 4.065 &, $000^{*}$ \\
\hline Vertical Jump $(\mathrm{cm})$ & $42.61 \pm 11.48$ & $32.47 \pm 11.06$ & 5.953 &, $000^{*}$ \\
\hline Flamingo Balance Test & $6.33 \pm 7.18$ & $0.46 \pm 2.78$ & 7.734 &, $000^{*}$ \\
\hline Sit-Reach Test $(\mathrm{cm})$ & $15.47 \pm 7.88$ & $9.49 \pm 5.74$ & 5.919 &, $000^{*}$ \\
\hline
\end{tabular}


Ahmet Kurtoğlu, Nurettin Konar

A COMPARISON OF SOME ANTHROPOMETRIC AND MOTOR FEATURES OF

VISUALLY IMPAIRED STUDENTS WHO PLAY SPORTS AND THOSE WHO DO NOT PLAY SPORTS IN SCHOOLS FOR THE VISUALLY IMPAIRED IN TURKEY

\begin{tabular}{|l|c|c|c|c|}
\hline \hline Standing Long Jump (cm) & $145.63 \pm 37.46$ & $103.05 \pm 32.26$ & 8.164 &, $000^{*}$ \\
\hline Sit-Up Test (no.) & $19.12 \pm 3.98$ & $13.40 \pm 4.91$ & 8.267 &, $000^{*}$ \\
\hline Bent Arm Hang (s) & $2.87 \pm 3.52$ & $0.28 \pm 1.30$ & 7.029 &, $000^{*}$ \\
\hline 10x5m Shuttle Run (s) & $23.55 \pm 3.33$ & $28.74 \pm 3.82$ & -9.395 &, $000^{*}$ \\
\hline
\end{tabular}

*Significance level was set at $\mathrm{p}<0.05$.

Looking at Table 6, it can be seen that significant differences were found between averages of grip strength, vertical jump, flamingo balance test, sit-reach test, standing long jump, sit-up test and 10x5 shuttle run in female visually impaired students who played sports and those in female visually impaired students who did not play sports $(p<0.05)$, whereas no significant difference was found in the bent arm hang test $(p>0.05)$.

Table 6: Comparison of Motor Features of Female Visually Impaired Students Playing Sports and of Female Visually Impaired Students Not Playing Sports

\begin{tabular}{|l|c|c|c|c|}
\hline Parameters & $\begin{array}{c}\text { Playing Sports } \\
(\mathbf{n = 2 6 )} \mathbf{X} \pm \mathbf{s s}\end{array}$ & $\begin{array}{c}\text { Not Playing Sports } \\
\text { (n=79) } \mathbf{X} \pm \mathbf{s s}\end{array}$ & $\mathbf{t}$ & $\mathbf{p}$ \\
\hline Grip Strength (kg) & $29.11 \pm 17.01$ & $16.06 \pm 12,46$ & 4.212 &, $000^{*}$ \\
\hline Vertical Jump (cm) & $34.69 \pm 12.43$ & $27.84 \pm 11.40$ & 2.595 &, $011^{*}$ \\
\hline Flamingo Balance Test & $5.42 \pm 8.17$ & $0.67 \pm 2.92$ & 2.904 &, $007^{*}$ \\
\hline Sit-Reach Test (cm) & $16.76 \pm 6.20$ & $12.40 \pm 8.16$ & 2.496 &, $014^{*}$ \\
\hline Standing Long Jump (cm) & $139.57 \pm 25.36$ & $90.00 \pm 28.05$ & 7.028 &, $000^{*}$ \\
\hline Sit-Up Test (no.) & $15.00 \pm 3.47$ & $11.17 \pm 8.33$ & 2.268 &, $025^{*}$ \\
\hline Bent Arm Hang (s) & $0.46 \pm 1.17$ & $0.03 \pm 0.33$ & 1.815 &, 081 \\
\hline 10x5m Shuttle Run (s) & $24.94 \pm 2.23$ & $29.24 \pm 3.24$ & -7.529 &, $000^{*}$ \\
\hline
\end{tabular}

*Significance level was set at $\mathrm{p}<0.05$.

Examination of Table 7 shows that significant differences were found between strength averages for abdomen, back, hip flexion, hip extension, leg flexion, leg extension, arm flexion and arm extension in male visually impaired students who played sports and those in male visually impaired students who did not play sports $(p<0.05)$.

Table 7: Comparison of Strength Measurements of Male Visually Impaired Students Playing Sports and of Male Visually Impaired Students Not Playing Sports

\begin{tabular}{|c|c|c|c|c|}
\hline Parameters & $\begin{array}{c}\text { Playing Sports } \\
(n=72) X \pm s s\end{array}$ & $\begin{array}{c}\text { Not Playing Sports } \\
(n=110) X \pm s s\end{array}$ & $\mathbf{t}$ & p \\
\hline Abdominal Strength (0-5) & $4.81 \pm 0.58$ & $3.93 \pm 0.73$ & 8.963 & $.000^{*}$ \\
\hline Back Strength (0-5) & $4.73 \pm 0.50$ & $3.93 \pm 0.70$ & 8.903 & $.000^{*}$ \\
\hline Hip Flexion Strength (0-5) & $4.61 \pm 0.49$ & $4.01 \pm 0.46$ & 8.109 & $.000^{*}$ \\
\hline Hip Extension Strength (0-5) & $4.62 \pm 0.48$ & $4.03 \pm 0.44$ & 8.223 & $.000^{*}$ \\
\hline Leg Flexion Strength (0-5) & $4.66 \pm 0.47$ & $4.01 \pm 0.48$ & 8.912 & $.000^{*}$ \\
\hline Leg Extension Strength (0-5) & $4.66 \pm 0.47$ & $4.04 \pm 0.53$ & 8.231 & $.000^{*}$ \\
\hline Arm Flexion Strength $(0-5)$ & $4.33 \pm 0.67$ & $3.64 \pm 0.59$ & 7.216 & $.000^{*}$ \\
\hline Arm Extension Strength (0-5) & $4.33 \pm 0.67$ & $3.64 \pm 0.64$ & 6.930 & $.000^{*}$ \\
\hline
\end{tabular}

${ }^{*}$ Significance level was set at $\mathrm{p}<0.05$. 
Examining Table 8, it is seen that significant differences were found between strength averages for abdomen, back, hip flexion, hip extension, leg flexion, leg extension, arm flexion and arm extension in female visually impaired students who played sports and those in female visually impaired students who did not play sports $(p<0.05)$.

Table 8: Comparison of Strength Measurements of Female Visually Impaired Students Playing Sports and of Female Visually Impaired Students Not Playing Sports

\begin{tabular}{|l|c|c|c|c|}
\hline Parameters & $\begin{array}{c}\text { Playing Sports } \\
(\mathbf{n = 2 6 )} \mathbf{X} \pm \mathbf{s s}\end{array}$ & $\begin{array}{c}\text { Not Playing Sports } \\
(\mathbf{n = 7 9 )} \mathbf{X} \pm \mathbf{s s}\end{array}$ & $\mathbf{t}$ & $\mathbf{p}$ \\
\hline Abdominal Strength (0-5) & $4,42 \pm 0,64$ & $3,75 \pm 0,70$ & 8,963 & $.000^{*}$ \\
\hline Back Strength (0-5) & $4,50 \pm 0,64$ & $3,73 \pm 0,69$ & 8,903 & $.000^{*}$ \\
\hline Hip Flexion Strength (0-5) & $4,57 \pm 0,50$ & $3,93 \pm 0,46$ & 8,109 & $.000^{*}$ \\
\hline Hip Extension Strength (0-5) & $4,61 \pm 0,49$ & $3,86 \pm 0,47$ & 8,223 & $.000^{*}$ \\
\hline Leg Flexion Strength (0-5) & $4,53 \pm 0,50$ & $3,79 \pm 0,49$ & 8,912 & $.000^{*}$ \\
\hline Leg Extension Strength (0-5) & $4,53 \pm 0,50$ & $3,78 \pm 0,49$ & 8,231 & $.000^{*}$ \\
\hline Arm Flexion Strength (0-5) & $4,15 \pm 0,46$ & $3,49 \pm 0,52$ & 7,216 & $.000^{*}$ \\
\hline Arm Extension Strength (0-5) & $4,11 \pm 0,43$ & $3,45 \pm 0,52$ & 6,930 & $.000^{*}$ \\
\hline
\end{tabular}

Significance level was set at $\mathrm{p}<0.05$.

\section{Discussion}

In our study, in male visually impaired students who played sports, average age was determined as $X=13.76 \pm 1.49$ years, average height as $X=159.33 \pm 13.22 \mathrm{~cm}$, average body weight as $X=50.85 \pm 18.23 \mathrm{~kg}$ and average $B M I$ values as $X=19.56 \pm 4.41 \mathrm{~kg} / \mathrm{m}^{2}$.In male visually impaired students who did not play sports, however, average age was determined as $X=13.40 \pm 1.55$ years, average height as $X=152.76 \pm 11.25 \mathrm{~cm}$, average body weight as $X=48.19 \pm 17.93 \mathrm{~kg}$ and average $B M I$ values as $X=20.24 \pm 5.45 \mathrm{~kg} / \mathrm{m}^{2}$. Following statistical analysis, whilst no significant differences were found in average age, body weight and BMI values of male visually impaired students who played sports and those who did not play sports ( $\mathrm{p}>0.05)$, a significant difference was found in average height $(\mathrm{p}<0.05)$.

Comparison of our research findings with those in the literature shows that there are similarities, with regard to age and height, with the measurements made on some anthropometric and motor features of students aged 12-14 who played sports and who did not play sports in the study made by Günay et al., but that different results were obtained with regard to body weight (17). In Kızılakşam's study, in which Eurofit Test Battery results were compared in students aged 12-14 who played sports and who did not play sports, different results were obtained with regard to age, height and body weight (18). Regarding BMI values of participants in our study, similar results were obtained to the BMI values of participants in the study made by Bilim et al., which examined physical fitness in students aged 12-17 who played sports and who did not play sports. Regarding age and height, however, different results were obtained to those of Bilim (19). 
In our study, in female visually impaired students who played sports, average age was determined as $X=13.57 \pm 1.27$ years, average height as $X=156.65 \pm 8.27 \mathrm{~cm}$, average body weight as $X=47.98 \pm 10.79 \mathrm{~kg}$ and average BMI values as $X=19.58 \pm 4.52 \mathrm{~kg} / \mathrm{m}^{2}$.In female visually impaired students who did not play sports, however, average age was determined as $X=12.82 \pm 1.43$ years, average height as $X=149.02 \pm 9.54 \mathrm{~cm}$, average body weight as $X=44.79 \pm 14.53 \mathrm{~kg}$ and average $B M I$ values as $X=19.86 \pm 4.85 \mathrm{~kg} / \mathrm{m}^{2}$.Following statistical analysis, whilst significant differences were found in average age and height of female visually impaired students who played sports and those who did not play sports $(p<0.05)$, no significant difference was found in average weight or BMI values $(p>0.05)$.

When comparing values obtained in our study with those found in the study made by Günay et al. on some anthropometric and motor features of students aged 12-14 who played sports and who did not play sports, different results were obtained in terms of age, height and body weight (17).It is considered that this dissimilarity may be due to the fact that Günay et al's study was made on the 12-14 age group, whereas ours was made on the 12-15 age group. In the study made by Gamal, in which anthropometric features and general health status of male and female students who participated in sports were compared, similar results were obtained with regard to BMI values. In Kizilakşam's study, in which Eurofit Test Battery results were compared in students aged 12-14 who played sports and who did not play sports, similar results were obtained to those of our study with regard to height and body weight (18).

In our study, in male visually impaired students who played sports, average shoulder girth was determined as $X=94.38 \pm 15.98 \mathrm{~cm}$, average chest girth as $X=76.30 \pm 9.67$ $\mathrm{cm}$, average upper arm girth as $X=22.12 \pm 3.57 \mathrm{~cm}$, average abdominal girth as $X=69.37 \pm 11.51 \mathrm{~cm}$, average hip girth as $X=82.36 \pm 12.65 \mathrm{~cm}$, average upper leg girth as $X=39.05 \pm 6.21 \mathrm{~cm}$ and average lower leg girth as $X=29.90 \pm 5.15 \mathrm{~cm}$. In male visually impaired students who did not play sports, however, average shoulder girth was determined as $X=92.04 \pm 14.20 \mathrm{~cm}$, average chest girth as $X=76.82 \pm 10.70 \mathrm{~cm}$, average upper arm girth as $X=22.26 \pm 4.13 \mathrm{~cm}$, average abdominal girth as $X=71.47 \pm 13.47 \mathrm{~cm}$, average hip girth as $X=80.25 \pm 14.66 \mathrm{~cm}$, average upper leg girth as $X=38.64 \pm 8.03 \mathrm{~cm}$ and average lower leg girth as $X=29.47 \pm 5.05 \mathrm{~cm}$. The statistical analysis made did not reveal any significant difference in girth measurement averages between male visually impaired students who played sports and those who did not play sports $(\mathrm{p}>0.05)$.

In our study, in female visually impaired students who played sports, average shoulder girth was determined as $X=91.96 \pm 8.34 \mathrm{~cm}$, average chest girth as $X=77.69 \pm 9.69$ $\mathrm{cm}$, average upper arm girth as $X=22.07 \pm 2.78 \mathrm{~cm}$, average abdominal girth as $X=68.92 \pm 9.43 \mathrm{~cm}$, average hip girth as $X=83.92 \pm 10.53 \mathrm{~cm}$, average upper leg girth as $X=38.88 \pm 5.22 \mathrm{~cm}$ and average lower leg girth as $X=30.42 \pm 6.79 \mathrm{~cm}$. In female visually impaired students who did not play sports, however, average shoulder girth was determined as $X=90.60 \pm 16.27 \mathrm{~cm}$, average chest girth as $X=76.49 \pm 10.32 \mathrm{~cm}$, average upper arm girth as $X=21.87 \pm 4.08 \mathrm{~cm}$, average abdominal girth as $X=69.78 \pm 12.25 \mathrm{~cm}$, average hip girth as $X=82.07 \pm 12.38 \mathrm{~cm}$, average upper leg girth as $X=38.36 \pm 6.46 \mathrm{~cm}$ and average lower 
leg girth as $X=29.05 \pm 4.94 \mathrm{~cm}$. Following the statistical analysis made, no significant differences were found in girth measurement averages between male visually impaired students who played sports and those who did not play sports $(\mathrm{p}>0.05)$.

Similar findings were obtained in our study to those obtained in Yilmaz's study, in which anthropometric and anthropometric features of male and female National badminton players and those playing in local leagues were compared(20).

In our study, in male visually impaired students who played sports, average grip strength was determined as $X=36.80 \pm 20.40 \mathrm{~kg}$, average vertical jump as $X=225.84 \pm 21.15$ $\mathrm{cm}$, average flamingo balance test as $X=6.33 \pm 7.18$, average sit-reach test as $X=15.47 \pm 7.88$ $\mathrm{cm}$, average standing long jump as $X=145.63 \pm 37.46 \mathrm{~cm}$, average number of sit-ups as $X=19.12 \pm 3.98$, average bent arm hang as $X=2.87 \pm 3.52$ seconds and average $10 \times 5$ shuttle run as $X=23.55 \pm 3.33$ seconds. In male visually impaired students who did not play sports, however, average grip strength was determined as $X X=24.58 \pm 19.45 \mathrm{~kg}$, average vertical jump as $X=208.05 \pm 15.54 \mathrm{~cm}$, average flamingo balance test as $X=0.46 \pm 2.78$, average sitreach test as $X=9.49 \pm 5.74 \mathrm{~cm}$, average standing long jump as $X X=103.05 \pm 32.26 \mathrm{~cm}$, average number of sit-ups as $X=13.40 \pm 4.91$, average bent arm hang as $X=0.28 \pm 1.30$ seconds and average $10 \times 5$ shuttle run as $X=28.74 \pm 3.82$ seconds. Following the statistical analysis made, a significant difference between the motor features of male visually impaired students who played sports and of those who did not play sports was determined $(\mathrm{p}<0.05)$.

Similar findings were obtained in our study to those obtained in the study made by Bilim, in which motor features of male students aged 12-17 who played sports and of those who did not play sports were compared (19).Similar results were found in our study to those found in the study made by Kızılakşam, in which anthropometric and motor features of students in the 12-14 age group who played sports and who did not play sports were compared using the Eurofit Test Battery, with the exception of grip strength and flamingo balance test results (18). It is considered that the reasons for the dissimilarity in grip strength and flamingo balance test results between the two studies may be the smaller age range of the participants of Kızılakşam's study and lower body balance ability in the visually impaired $(21,22)$.

In our study, in female visually impaired students who played sports, average grip strength was determined as $29.11 \pm 17.01 \mathrm{~kg}$, average vertical jump as $X=214.42 \pm 14.40 \mathrm{~cm}$, average flamingo balance test as $X=5.42 \pm 8.17$, average sit-reach test as $X=16.76 \pm 6.20 \mathrm{~cm}$, average standing long jump as $X=139.57 \pm 25.36 \mathrm{~cm}$, average number of sit-ups as $X=15.00 \pm 3.47$, average bent arm hang as $X=0.46 \pm 1.17$ seconds and average $10 \times 5$ shuttle run as $X=24.94 \pm 2.23$ seconds. In female visually impaired students who did not play sports, however, average grip strength was determined as $X=16.06 \pm 12.46 \mathrm{~kg}$, average vertical jump as $X=197.68 \pm 15.84 \mathrm{~cm}$, average flamingo balance test as $X=0.67 \pm 2.92$, average sit-reach test as $X=12.40 \pm 8.16 \mathrm{~cm}$, average standing long jump as $X=90.00 \pm 28.05$ $\mathrm{cm}$, average number of sit-ups as $X=11.17 \pm 8.33$, average bent arm hang as $X=0.03 \pm 0.33$ seconds and average $10 \times 5$ shuttle run as $X==29.24 \pm 3.24$ seconds. Following the statistical 
analysis made, a significant difference between the motor features of male visually impaired students who played sports and the motor features of those who did not play sports was determined $(\mathrm{p}<0.05)$.

Similar findings were obtained in our study to those obtained in the study made by Bilim, in which motor features of female students aged 12-17 who played sports and of those who did not play sports were compared (19). Similar results were obtained to those in the studies carried out by Çalışkan et al. on the physical fitness of visually impaired children (23).

In our study, in male visually impaired students who played sports, average abdominal strength was determined as $X=4.81 \pm 0.58$, average back strength as $X=4.73 \pm 0.50$, average hip flexion strength as $X=4.61 \pm 0.49$, average hip extension strength as $X=4.62 \pm 0.48$, average leg flexion strength as $X=4.66 \pm 0.47$, average leg extension strength as $X=4.66 \pm 0.47$, average arm flexion strength as $X=4.33 \pm 0.67$ and average leg extension strength as $X=4.33 \pm 0.67$.In male visually impaired students who did not play sports, however, average abdominal strength was determined as $X=3.93 \pm 0.73$, average back strength as $X=3.93 \pm 0.70$, average hip flexion strength as $X=4.01 \pm 0.46$, average hip extension strength as $X=4.03 \pm 0.44$, average leg flexion strength as $X=4.01 \pm 0.48$, average leg extension strength as $X=4.04 \pm 0.53$, average arm flexion strength as $X=3.64 \pm 0.59$ and average leg extension strength as $X=3.64 \pm 0.64$.Following the statistical analysis made, significant differences were found between the strength parameters of male visually impaired students who played sports and of those who did not play sports $(p<0.05)$.

The results are similar to those obtained in the study made by Yağcl et al., in which they compared balance ability in the hearing disabled (24).

In our study, in female visually impaired students who played sports, average abdominal strength was determined as $X=4.42 \pm 0.64$, average back strength as $X=4.50 \pm 0.64$, average hip flexion strength as $X=4.57 \pm 0.50$, average hip extension strength as $X=4.61 \pm 0.49$, average leg flexion strength as $X=4.53 \pm 0.50$, average leg extension strength as $X=4.53 \pm 0.50$, average arm flexion strength as $X=4.15 \pm 0.46$ and average leg extension strength as $X=4.11 \pm 0.43$.In female visually impaired students who did not play sports, however, average abdominal strength was determined as $X=3.75 \pm 0.70$, average back strength as $X=3.73 \pm 0.69$, average hip flexion strength as $X=3.93 \pm 0.46$, average hip extension strength as $X=3.86 \pm 0.47$, average leg flexion strength as $X=3.79 \pm 0.49$, average leg extension strength as $X=3.78 \pm 0.49$, average arm flexion strength as $X=3.49 \pm 0.52$ and average leg extension strength as $X=3.45 \pm 0.52$. Following the statistical analysis made, significant differences were found between the strength parameters of female visually impaired students who played sports and of those who did not play sports $(\mathrm{p}<0.05)$.

The study made by Akyol, examining the effect of callisthenic exercises on muscle strength, flexibility, pain intensity and body mass index in sedentary women with back pain, shows similar results to those of our study (25). 


\section{Conflict of Interest Statement}

There is no conflict of interest in this study.

\section{About the Author}

Ahmet Kurtoğlu, Research Assistant, İnönü University, Health Sciences Institute. Research interests: physiology, exercise for the disabled people, training sciences. orcid.org/0000-0002-9292-5419

Prof. Nurettin Konar, Department of Physical Education and Sport, Turgut Ozal University, Battalgazi, Malatya. Research interests: education and exercise for disabled people. orcid.org/0000-0002-2542-7524

\section{References}

1. T. C. Başbakanlık Özürlüler İdaresi ve DİE, 2002 Türkiye Özürlüler Araştırması - SIS, Turkey Disability Survey 2006.

2. Ölmez E. Görme Engelli Bireylerin Sosyalleşme Sürecine Sporun Etkisi, Gazi Üniversitesi Eğitim Bilimleri Enstitüsü, Beden Eğitimi ve Spor Anabilim Dalı. (Yüksek Lisans Tezi), Ankara: Gazi Üniversitesi 2010.

3. Konar N. Rehabilitasyon - Engelliler Sporu ve Paralimpikler, İstanbul Üniversitesi, Spor Bilimleri Dergisi 2013, 11 (3): 162- 6.

4. Konar N. Einführungdes Kinder- und Jugendsportsfür Körperbehinderte in der Türkei, Institut für Rehabilitation und Behinderten sport, (Dissertation), Köln: Deutsche Sporthochschule 2006.

5. Maggill R. A. Motor Learning, Wm. C. Brown Comp. Publ., USA 1980: 66-124

6. O'Connell M. The Effect of Brailling and Physical Guidance on the Self Efficacy of Children Who are Blind, Unpublished Master's Thesis: State University of New York College at Brockport, NY, 2000.

7. Lieberman L, Cowart, J. Games for People with Sensory Impairments: Strategies for Including Individuals of all Ages, Champagne, IL: Human Kinetics, 1996.

8. Lieberman L, Taule 1. Including Physical Fitness into the Lives of Individuals Who are Deaf-Blind, Deaf-blind Perspectives, 1998, 5(2): 6-10.

9. Çalışkan, E. Goalball Sporunun Görme Engelli Çocukların Fiziksel Uygunluk, Postür ve Kaygı Durumlarına Etkilerinin Değerlendirilmesi, Marmara Üniversitesi, Sağlık Bilimleri Enstitüsü, Yayınlanmamış Doktora Tezi, İstanbul, 2004.

10. Council of Europe, (1988). Handbook of Eurofit, https://www.coe.int/T/E/cultural cooperation/Sport/Sport for all/Eurofit/ Erişim:28.03.2018;18:28.

11. Winnick, J. P. \& Short, F. X. (1999). The Brockport Physical Fitness Test Manual. Champaign, IL: Human Kinetics.

12. Otman A. S., Köse N., Tedavi Hareketlerinde Temel Değerlendirme Prensipleri, 4.bask1, Ankara, 2008. 
13. http://sgb.meb.gov.tr/www/icerik goruntule.php?KNO=270 (Erişim Tarihi: $13 / 01 / 2018)$

14. WHO (1995a). Physical Status: The Use and Interpretation of Anthropometry. Report of a WHO Expert Committee. WHO Technical Report Series 854. Geneva, WHO.

15. WHO (2010):: Global Database on Body Mass Index. (Access: 24 Nov, 2010). (www.apps.who.int/bmi/index.jsp?introPage=intro 3.html)

16. Gamal M. T., Physical Fitness and Health Status of Sport Student in Germany and Egypt, Technische Universitaet Chemnitz, Germany, 2011.

17. Günay M., Ciğerci A. E., Aksen P. The Evaluation of Some Physical and Motor Features of The Female and Male Students Aged 12-14 Who Participated in Sport or Not, Bulletin of the Transilvania University of Braşov 2011, 4 (53): 203-10.

18. Kızılakşam E., Edirne İl Merkezi İlköğretim Okullarındaki 12-14 Yaş Grubu Aktif Olarak Spor Yapan ve Yapmayan (Beden Eğitimi Dersine Giren) Öğrencilerin Eurofit Test Bataryaları Uygulama Sonuçlarının Değerlendirilmesi, Sağlık Bilimleri Enstitüsü, Beden Eğitimi ve Spor Anabilim Dalı (Yüksek Lisans Tezi), Edirne: Trakya Üniversitesi 2006.

19. Bilim A. S., 12-17 Yaş Arası Spor Yapan ve Spor Yapmayan Öğrencilerin Fiziksel Uygunluklarının İncelenmesi, Sağlık Bilimleri Enstitüsü, Beden Eğitimi ve Spor Anabilim Dalı (Yüksek Lisans Tezi), İzmir: Dokuz Eylül Üniversitesi, 2013.

20. Yılmaz, N., Milli Takım ve Mahalli Liglerde Oynayan Badmintoncuların Antropometrik Özellikleri ile Çabukluk, Esneklik ve Dayanıklılıklarının Araştırılması, Sağlık Bilimleri Enstitüsü, Beden Eğitimi ve Spor Anabilim Dalı (Yüksek Lisans Tezi), Kütahya: Dumlupınar Üniversitesi 2013.

21. Kaya, M. "13-15 Yaş grubu spor yapan görme engellilerin statik ve dinamik denge etkinliklerinin karşılaştırılması." Gazi Üniversitesi Sağlık Bilimleri Enstitüsü, Beden Eğitimi ve Spor A.B.D.Yüksek Lisans, Ankara, 2003.

22. Tükel, Y.: "Görme Engelli Judocuların Denge Performanslarının İncelenmesi" Selçuk Üniversitesi, Sağllk Bilimleri Enstitüsü, Beden Eğitimi ve Spor A.B.D.Yüksek Lisans, Konya, 2015.

23. Çalışkan, E.; Pehlivan, A.; İnal, S.; Dane, Ş.; Akar, S.: Goalball Sporunun ve Hareket Eğitiminin Görme Engelli Çocukların Fiziksel Uygunluk Üzerine Etkilerinin Değerlendirilmesi, Atatürk Üniversitesi Beden Eğitimi ve Spor Bilimleri Dergisi, 2006, 8 (3): 3-11.

24. Yağcı N., Cavlak U., Şahin G. İşitme Engellilerde Denge Yeteneğinin İncelenmesi Üzerine Bir Çalışma, KBB-Forum 2004, 3 (2): 45-50.

25. Akyol B., Arslan C., Çolak C. Üst Ekstremite ve Bel Ağrısı Tanısı Konulan Sedanter Kadınlarda Kalistenik Egzersizlerin Ağrı Eşiği, Ağrı Şiddeti ve Kas Kuvveti Üzerine Etkisi, Turgut Özal Tip Merkezi Dergisi 2016, 23 (1): 29-35. 

copy, distribute, transmit or adapt the article content, providing a proper, prominent and unambiguous attribution to the authors in a manner that makes clear that the materials are being reused under permission of a Creative Commons License. Views, opinions and conclusions expressed in this research article are views, opinions and conclusions of the author(s). Open Access Publishing Group and European Journal of Physical Education and Sport Science shall not be responsible or answerable for any loss, damage or liability caused in relation to/arising out of conflict of interests, copyright violations and inappropriate or inaccurate use of any kind content related or integrated on the research work. All the published works are meeting the Open Access Publishing requirements and can be freely accessed, shared, modified, distributed and used in educational, commercial and non-commercial purposes under a Creative Commons attribution 4.0 International License (CC BY 4.0). 